\section{THE RANSOMING OF PRISONERS TAKEN FROM THE ARMADA, 1589-1590}

THE 2006 inventory made of parts of the de Bergeyck family archive, preserved in Cortewalle Castle located in the village of Beveren near Antwerp, led to a startling discovery. Quite unexpectedly, archivist Stefanie Audenaert found a list of 494 individuals taken captive by the English between early August and early November of 1588, during and after the Spanish Armada's operations in the English Channel. ${ }^{1}$ With few exceptions, there were no officers or other prominent members of the Armada among them. Essentially, the roll is comprised of ordinary soldiers and sailors without the means to buy their own release via a handy and substantial lump sum. ${ }^{2}$ Instead, they were ransomed en masse by Philip II in January of 1590, and it is in this context that the list was compiled. Their release was organized via the Spanish Netherlands, under the supervision of Alexander Farnese. The governor-general charged Charles Longin, commissaire ordinaire des monstres of Spain's army in the Low Countries, with paying the ransom and expenses incurred, as well as the practical implementation of the entire operation. ${ }^{3}$ In 1615 , Longin died childless and parts of his estate, including his personal papers, ended up with his sister Catharina, the spouse of Johannes de Visscher. Later, the de Visscher and de Bergeyck families were united in marriage, and thus Longin's papers, along with the list, were eventually bequeathed to the archive of the Counts of Bergeyck.

\footnotetext{
${ }^{1}$ Archive de Bergeyck Beveren [ABB], sub-fonds de Visscher de Celles, nr. 1214, s.f.

2 The only exceptions to this are a few officers who were aboard the Trinidad Valencera, such as captain Juan Hidalgo. For some unknown reason, his attempt to purchase his own freedom failed. In the end, a ransom six times that asked for other captives was paid (ABB, subfonds de Visscher de Celles, 1214, s.f.).

${ }^{3}$ The muster-master was an official appointed by the king. All captains had to submit their levies to him, and the muster-master examined the company's list, scrutinized each name and every man to ensure that the recruit was an actual soldier and not a page or a suborned peasant, and finally signed a declaration at the end of the roll certifying the number of men present; G. Parker, The Army of Flanders and the Spanish Road, 1567-1659 (Cambridge, 1972), 37.
}

The document, which is comprised of around 140 unnumbered pages, bears no exact date. However, it is clearly one of the fair copies made of Longin's final expense account. At the end of 1589, Longin joined the delegation that travelled via three flyboats from Dunkirk to Dartmouth to take charge of the prisoners. And indeed, a declaration at the top of the document states that it is 'the list of prisoners that I, Carlos Longin... in accordance with the orders of the Duke of Parma and Plasencia, GovernorGeneral of the Netherlands, have redeemed'. From the dates given, it appears that the majority of the releases took place during the second half of January; ${ }^{5}$ only one captive was set free much later, on 10 March 1590the date noted next to his name. ${ }^{6}$ Around 1 February 1590, three ships carrying the prisoners already ransomed sailed from Dartmouth for the Iberian Peninsula. A couple of weeks later they arrived in the Galician ports of La Coruña and Ferrol, thus bringing to an end their Armada adventure.?

This short essay explores what may be potentially derived from the list, which consists of much more than a simple series of names. Other data were also included. Not consistently, but often enough to aid in constructing a detailed picture of the individuals involved. It is hoped that the examination and analysis of this information will make a small contribution to the well-established history of the Armada, and the fate of its soldiers and sailors.

\section{The Data Contained in the List}

In most cases, prisoners were listed with the following information: first and last name, the first and last name of his father, his place of residence, and a brief physical description. The latter indicates that Longin prepared the list in situ, and in the presence of the captives.

\footnotetext{
${ }^{4}$ ABB, sub-fonds de Visscher de Celles, 1214, s.f. (first page).

5 This was also confirmed in a letter from Philip II to Farnese of 30 January 1590; J. Lefèvre, Correspondance de Philippe II sur les affaires des Pays-Bas, III (Brussels, 1956), 466-7.

${ }^{6}$ ABB, sub-fonds de Visscher de Celles, 1214, s.f.

P. Martin, Spanish Armada Prisoners. The story of the Nuestra Señora del Rosario and her crew, and of other prisoners in England, 1587-97 (Exeter, 1988), 56.
} 
It may be that these descriptions were included in order to prove that the individuals in question were actually being held, and that all the funds disbursed were used to redeem genuine prisoners. In addition, their age was noted, as was their tercio, or regiment, and the company to which the prisoner belonged. The name of their ship was often included as well, and this plus the general muster taken just before the Armada left La Coruña in July 1588 showing which craft carried which company, ${ }^{8}$ means that it is possible to determine the vessel of most of the individual crew members. Other data are also included on occasion, such as the soldier's rank, or the sailor's duties.

After these biographical details came a summary of the amounts spent on each captive. First the ransom was noted, which was a general tariff of 17 pounds sterling per individual - or the equivalent of 51 Brabant guilders $(\mathrm{fl})^{9}$ - -then the maintenance expenses incurred during captivity such as food and, if necessary, clothing. Rations were reckoned at 5 placcas, or a quarter of a guilder, per day. The amount spent on food varied from around 90 to $125 \mathrm{fl}$, depending upon the provisions found on the captured ships that could be fed to the prisoners, ${ }^{10}$ and the length of their captivity (cf. below). Lastly, Longin noted the value of any new apparel he provided to those who required it upon their release. One example of such an entry reads as follows:

Domingo Hernandez, h[ijo] de Lorenco Hernandez, n[atural] de Salamanca, de buen cuerpo, con una señal grande encima de la ceja derecha, desbarvado, de 26 años, de la compa[gni]a de Don Pedro de Leon. Por su rescatte: 51 florines. Por su comida: 120 florines 10 placcas. Ropilla, calcones, camisa, un par de çapatos: 6 florines 10 placcas. Medias: 1 florin. Despues le he dado jubon: 3 florines; camisa, 1 florin 10 placcas; medias, 0 florines 15 placcas; çapatos, 1 florin.

\footnotetext{
${ }^{8}$ C. Martin and G. Parker, The Spanish Armada, 2nd edn (Manchester, New York, 1999), 19.

9 See the notation ' 17 libras de a tres florines, que son 51 florines'; ABB, sub-fonds de Visscher de Celles, 1214, s.f. (first page).

${ }^{10}$ Martin, Spanish Armada Prisoners, 44.
}

[Domingo Hernández, son of Lorenzo Hernández, born and raised in Salamanca, solidly built and with a large scar above the right eyebrow, beardless, 26 years old, of the company of Don Pedro de León. For his ransom, $51 \mathrm{fl}$. For his food, $120 \mathrm{fl}$ and 10 placcas. Short jacket, breeches, shirt, a pair of shoes, $6 \mathrm{fl}$ and 10 placcas. Stockings: $1 \mathrm{fl}$. Afterwards I gave him: a doublet, $3 \mathrm{fl}$; a shirt, $1 \mathrm{fl} 10$ placcas; stockings, 15 placcas; shoes, $1 \mathrm{fl}$.]

The release of Domingo Hernández cost a total of $185 \mathrm{fl}$ and 5 placcas, which covered his ransom, food, and garb provided during his captivity, and the clothing he was given for the trip home. The expenses incurred by almost all of the redeemed individuals were listed in this fashion, and to cover the entire operation, Longin had 80,000 Brabant guilders - approximately 27,000 pounds sterling at his disposal, or an average of $160 \mathrm{fl}$ per prisoner. $^{1}$

\section{Age and Origin}

The ages of the 447 captives are given with remarkable precision, and therefore some caution is advisable. Yet even if the specified age is not entirely accurate, it is still possible to assemble a reasonable picture of the age structure of this population of prisoners. The youngest is listed as being just 12 years old, while two at the other extreme are said to be 60 , while another is simply noted as 'viejo', or 'old'. However, as Table 1 demonstrates, the majority of the captives were between twenty and thirty years of age.

With regard to their origins, the lion's share of the ransomed prisoners hailed from the Crowns of Castile and Aragon, the two kingdoms that constitute contemporary Spain. There were still around thirty captives from other parts of Europe, however all nonSpanish prisoners of the Armada had been ordered set free in November of $1588 .{ }^{12}$ These captives on the list coming from other

\footnotetext{
11 One Brabant guilder was the equivalent of 20 placcas or pattars, and was worth 4 reales at that time; one Spanish escudo de oro was worth 3 Brabant guilders or 12 reales. See Charles Longin to Thomas Cotteels, 14 January 1590; ABB, sub-fonds de Visscher de Celles, 1215, s.f.

${ }^{12}$ Martin, Spanish Armada Prisoners, 48 and 51.
} 
Table 1. Captives by age

\begin{tabular}{ll}
\hline under 15 & 9 \\
$15-19$ & 39 \\
$20-29$ & 291 \\
$30-39$ & 81 \\
$40-49$ & 22 \\
$50-60$ & 5 \\
\hline
\end{tabular}

regions, originated in the Netherlands, Hanseatic cities, Portugal, and some parts of Italy, mainly Genoa. They were probably sailors as opposed to soldiers, and indeed this is sometimes noted next to their names. For example, one Juan Xivers from Hamburg is listed as a marinero of the Falcón Blanco Mayor, while twelve-year-old Georg Langes from Danzig was a gromete, or cabin boy, on the same vessel. André de Luts from 'sHertogenbosch and Andras Gaspar from Lisbon were marineros on the San Salvador, where Herman Pepper of Danzig was an artillero. Hans Pots from Nieuwpoort in Flanders was a marinero on the San Pedro Mayor.

The Spanish prisoners came from every corner of Castile and Aragon, strikingly, however, many were concentrated in certain regions. Approximately 430 of the 494 redeemed were listed with a place of origin, and no less than sixty-four of those called Écija in Andalusia home. This could be explained by the fact that they all belonged to the company of Captain Alonso de Zayas, which sailed on the Rosario; clearly, he had recruited in and around Écija. Approximately thirty other soldiers were from the neighbourhood of Lucena (near Cordoba), and they were among the companies belonging to Diego de Aler, which embarked for England on the San Pedro Mayor, and Juan de Ibarra, again of the Rosario.

\section{The Prisoners and Their Ships}

Of the 494 captives, it was possible to determine the ships of 382 . The breakdown is shown in Table 2.

Most of the prisoners had sailed aboard the Nuestra Señora del Rosario, a ship whose fortunes are well known to historians. Captained by don Pedro Valdés, it was the Armada's fourth largest vessel. The crew
Table 2. Captives by vessel

\begin{tabular}{ll}
\hline Nuestra Señora del Rosario & 243 \\
San Pedro Mayor & 65 \\
Trinidad Valencera & 27 \\
San Salvador & 12 \\
Lavia & 7 \\
Juliana & 5 \\
San Lorenzo & 4 \\
Falcón Blanco Mediano & 3 \\
Santa Maria de Visón & 3 \\
Falcón Blanco Mayor & 2 \\
Santa Bárbara & 2 \\
Ciervo Volante & 2 \\
San Nicolás Prodaneli & 2 \\
María Juan & 2 \\
Gran Grin & 1 \\
Nuestra Señora de Begoña & 1 \\
San Mateo & 1 \\
Vessel unaccounted for & 112 \\
\hline
\end{tabular}

numbered around 119 sailors, and it carried some 345 soldiers. The Rosario was the flagship of the Andalusian squadron, which comprised fifteen vessels in total. ${ }^{13}$ At the end of July of 1588, when the Armada sailed into the English Channel, the Rosario collided with other ships of the Spanish fleet, and was left behind as a result. On 1 August, Pedro Valdés surrendered to Francis Drake. ${ }^{14}$ The Rosario was towed to Tor Bay, presumably the nearest available harbour at the time. Afterwards, the ship, along with its soldiers and sailors, was sent onwards to Dartmouth. However, this did not include the few dozen officers able to pay a high ransom; they were already removed from the vessel. ${ }^{15}$

Besides the sailors and soldiers of the Rosario among the 494 prisoners, there were a large number from the San Pedro Mayor. This was the Armada's hospital ship, ${ }^{16}$ which, after rounding the British Isles, was hit and became stranded near Salcombe on the south Devon coast, not far from where the Armada had entered the English Channel three months earlier. Of the 158 people on board, only the 123 Spaniards were taken captive; the thirty-

\footnotetext{
13 Martin and Parker, The Spanish Armada, 263.

${ }_{14}$ Martin and Parker, The Spanish Armada, 150-3.

15 Martin, Spanish Armada Prisoners, 18 and 44.

16 M. Gracia Riva, La sanidad en la jornada de Inglaterra (1587-1588) (Madrid, 1988), 301-4.
} 
five French, Flemish, Italian, and Portuguese found on the vessel were released. ${ }^{17}$ Some of the captives were patients rather than part of the crew complement, and it is not clear from Longin's list whether the ship appended to prisoners' names is their original vessel, or simply the craft they were captured on.

About the same time that the Rosario fell into English hands, the Guipúzcoan San Salvador, one of the most heavily armed ships in the fleet, began having trouble. On 31 July, a massive explosion took place on board, followed by a fire. Half of the 400 people aboard were either killed or badly injured. The ship was swiftly abandoned, and shortly afterwards both it and a handful of surviving crewmen were captured by the English, who towed the craft into Weymouth. ${ }^{18}$ In all likelihood, most of the twelve people on board the San Salvador included on Longin's list were survivors of the explosion that had subsequently been transferred to the San Pedro Mayor for care; certainly, the list drawn up in November of 1588 of those on the hospital ship, included roughly a dozen men from the San Salvador. ${ }^{19}$

Other ships that went down in the English Channel were the San Lorenzo, the Maria Juan, and the San Mateo. Four prisoners on Longin's list claimed to be members of Luis Macián's company, which had embarked on the San Lorenzo. The vessel was a galeazza, the flagship of the galleasses from Naples, and it was destroyed off Calais following the fire ship attacks on the nights of 7 and 8 August. ${ }^{20}$ Two of Longin's prisoners came from the Maria Juan, which belonged to the Biscay Squadron, and was destroyed during the battle near Gravelines on 8 August. Of the 300 men on board, most went down with the ship and only a few dozen were rescued. $^{21}$ The San Mateo of the Portugal

17 Martin and Parker, The Spanish Armada, 263.

18 Martin and Parker, The Spanish Armada, 150. At the end of November 1588, the ship was being towed from Weymouth to Portsmouth when it sank without a trace, taking with it a number of prisoners who had survived the explosion (P. Martin, Spanish Armada Prisoners, 48).

${ }_{19}$ Martin, Spanish Armada Prisoners, 51. That is, for example, the case with Antonio de Ebriones ('de Bruones' in P. Martin, 101).

${ }_{20}$ Martin and Parker, The Spanish Armada, 175-6.
Squadron was also badly damaged during this encounter, and on the following night it ran aground in the shallow waters between Nieuwpoort and Ostend. While the Dutch captured most of its crew, one survivor fell into English hands and was subsequently ransomed by Longin.

Yet beyond a shadow of a doubt, the 'Enterprise of England' suffered its heaviest losses as a result of the storm that caused a considerable portion of the Armada to wreck along the northern and western coasts of Ireland as it attempted to return to Spain. It is certain that at least twenty-seven of the detainees were from the Trinidad Valencera, a large Venetian merchant ship that had been conscripted into carrying the Armada's heavy siege train as part of the Levant Squadron. Upon its departure from La Coruña, the vessel had seventy-five sailors and 338 soldiers on board. On 16 September 1588, the Trinidad ran aground in Kinnagoe Bay, County Donegal, on the north coast of Ireland. Of those who reached dry land, most were killed by Elizabeth I's English and Irish troops, but a few escaped and reached the Netherlands via Scotland with the aid of Irish rebels. ${ }^{22}$ Niall Fallon devoted several pages of The Armada in Ireland to the fate of the Trinidad and her crew, ${ }^{23}$ and his investigations showed that a party of roughly forty-two Spaniards were held to ransom following the massacre, but that only two remained alive long enough to be released. Little is known of the others, and Fallon suspected that most of them died in captivity. However, Longin's list shows that other survivors of the Trinidad were later ransomed as well, including the captains Juan Hidalgo and Jerónimo de Aybar, an auditor (or judge-advocate) by the name of Rodrigo Ponce de León, and sargento mayor Baltasar López.

\footnotetext{
21 Martin and Parker, The Spanish Armada, 178-9 and 262 .

22 Martin and Parker, The Spanish Armada, 213-14; D. Higueras Rodríguez and M. P. San Pío Aladrén, 'Irish wrecks of the Great Armada', in P. Gallagher and D. W. Cruickshank (eds), God's Obvious Design. Papers for the Spanish Armada Symposium (Sligo, 1988) (London, 1990), 146-8.

23 N. Fallon, The Armada in Ireland (London, 1978), 127-39.
} 
Longin also ransomed other passengers from ships destroyed off the coast of Ireland. Indeed, in some cases it is explicitly noted next to their names that 'se perdió en Irlanda', while others are grouped under the heading 'soldados venidos de Yrlanda'. These included the seven survivors of the Lavia, five from the Juliana, and three from the Santa Maria de Visón - all large merchantmen requisitioned by Spain to serve in the Levant Squadron like the Trinidad. These three ships, with a total compliment of around 1,000 sailors and soldiers, ${ }^{24}$ went down off the north-west coast of Ireland on 21 September, in the surf off Streedagh Beach, Sligo, in Donegal Bay. ${ }^{25}$ Less than 300 men were able to reach the shore, and most of them died at the hands of Sir Richard Bingham's troops. Bingham was the governor of the western province of Connacht, and acting on the orders of the Lord Deputy of Ireland, William Fitzwilliam, he showed no mercy to any Spanish refugees. Nevertheless, Longin's list shows that there were survivors of the massacre on Streedagh beach.

Other vessels that went down on Ireland's west coast such as the Gran Grin, the Falcón Blanco Mediano, the San Nicolás Prodaneli, and the Ciervo Volante, also had registered survivors on the list. Around 20 September, the Gran Grin, formerly a mercantile grain carrier, was driven into Clew Bay and ran aground off Clare Island with about 340 men on board. ${ }^{26}$ Only a hundred or so reached the shore, and the majority of those were killed by Bingham's local allies, the O'Malleys. ${ }^{27}$ The remainder, together with around 400 other Spanish prisoners, were hung in Galway prison on the orders of Fitzwilliam. ${ }^{28} \mathrm{~A}$ few, however, escaped execution: next to the name of Jayme Cortez, for example, Longin noted 'que venia en el Gran Grin'. A similar fate lay in store for the crew of the Falcón Blanco Mediano, a 300-tonne vessel of the Hulks Squadron with a compliment

\footnotetext{
24 Martin and Parker, The Spanish Armada, 263-4.

25 S. Birch and D. M. McElvogue, 'La Lavia, La Juliana and the Santa María de Visón: three Spanish Armada transports lost off Streedagh Strand, Co Sligo: an interim report', The International Journal of Nautical Archaeology, xxviii.3 (1999), 265-76; Higueras Rodríguez and San Pío Aladrén, 'Irish wrecks', 148-9.

26 Martin and Parker, The Spanish Armada, 262.

27 Martin and Parker, The Spanish Armada, 219.

${ }^{28}$ Higueras Rodríguez and San Pío Aladrén, 'Irish wrecks', 150-1.
}

of little more than 100 men. It was lost around 25 September off the coast of Connemara, near the island of Inishbofin. Nearly all the castaways fell into Bingham's hands and were executed in Galway. According to C. Martin and G. Parker, only the aristocrats don Luis de Córdoba and his nephew don Gonzalo were spared, to be ransomed and returned to Spain a year later. ${ }^{29}$ However, Longin's list shows that he redeemed at least three other survivors: Francisco Gallego from Osuna in southern Spain, Juan Xivers from Hamburg, and Gregorio Langes from Danzig.

Two of the captives claimed to be from the 'Bordonela'; in all likelihood this was the San Nicolás Prodaneli of the Levant Squadron, which sank off the Corraun Peninsula in County Mayo on the west coast of Ireland on 16 September. Around 300 men were on board, but barely a dozen survived. ${ }^{30}$ At about the same time and place, another of the Hulks Squadron, the Ciervo Volante, went down with about 170 sailors and soldiers aboard. Little is known of what happened to her, but two of the prisoners on Longin's list claimed to be survivors of this vessel. Two other men hailed from the Santa Bárbara, yet another of the Hulks Squadron. Previously, nothing was known of her fate but that she failed to return to the Iberian Peninsula. ${ }^{31}$ However, given that the two men are listed under the heading "los soldados venidos the Irlanda', it now seems likely that the Santa Bárbara was one of the ships that perished on Ireland's northern or western coastlines.

Finally, there were a few captives on the list from vessels that had managed to return to Spain. There was a single prisoner hailing from the Nuestra Señora de Begoña of the Castile Squadron, which carried a complement of eighty-one sailors and 202 soldiers, plus two men from the Falcón Blanco Mayor, of the Hulks Squadron, which had a total

\footnotetext{
29 Martin and Parker, The Spanish Armada, 223.

${ }^{30}$ C. Meide, Achill Island Maritime Archaeology Project: Report on archaeological and historical investigations, 2004 2005, unpublished report, William \& Mary (Williamsburg, Virginia), Institute of Maritime History (Tall Timbers, MD, 2006), 13-14; Fallon, The Armada in Ireland, 195-6.

31 M. J. Rodríguez Salgado, Armada 1588-1988. An international exhibition to commemorate the Spanish Armada (London, 1988), 155.
} 
complement of around $140 .{ }^{32}$ It seems likely that these three individuals had fetched up on another vessel during the voyage and thus were taken captive by the English via a different ship.

\section{Conclusion}

This list of Armada prisoners was found in a relatively small, private archive and its analysis has revealed some previously unknown details pertaining to the 'Enterprise of England'. The prisoners redeemed via the Spanish Netherlands had been stationed on at least seventeen different Armada ships, sunk or captured by the English, or wrecked following the now infamous storm. The majority of the captives were taken off several vessels lost in the English Channel early in August of 1588, as well as the hospital ship San Pedro Mayor, which was stranded off the South Devon coast a few months later. Most interestingly, however, the group ransomed by Longin also included several sailors and soldiers from vessels that went down off the coast of Ireland. Among them were crew members from the Santa Bárbara, which we now know certainly perished somewhere off the Irish coast. There the shipwrecked could expect no mercy at the hands of the Anglo-Irish forces, however it now seems that more survived than had previously been thought.

Ghent University

\section{RenÉ Vermeir}

doi:10.1093/notesj/gju264

(C) The Author (2015). Published by Oxford University Press. All rights reserved. For Permissions, please email: journals.permissions@oup.com Advance Access publication 6 February, 2015

32 Rodríguez Salgado, Armada 1588-1988, 155.

\section{THE INFLUENCE OF ROBERT GARNIER'S LES JUIFVES ON KYD'S THE SPANISH TRAGEDY}

ON the basis of some verbal, rhetorical, and thematic similarities 'of limited importance', ${ }^{1}$ Lukas Erne has asserted that Robert Garnier's tragedy Cornélie (1574), which was

\footnotetext{
1 Lukas Erne, Beyond 'The Spanish Tragedy': A Study of the Works of Thomas Kyd (Manchester, 2001), 212-15, 55.
}

translated by Thomas Kyd in 1594, 'is, in fact, the only contemporary play of which definite traces can be found in The Spanish Tragedy, and its influence on Kyd may have been of greater importance than that of any other play of his century'. However, Garnier's final tragedy and masterwork Les Juifves (1583) exerts a more developed and significant influence on The Spanish Tragedy (1587-91) through its depiction of interlocking levels of political and divine vengeance, as exemplified in the biblical narrative of King Zedekiah, and the related use of apocalyptic prophecy concerning the fall of Babylon.

In the dedication to Les Juifves, Garnier declares that he has depicted the calamities of the Jewish people, who abandoned their God through idolatry, to mirror the troubled contemporary situation in France. ${ }^{3}$ Garnier dramatizes the biblical events involving the oppression of Zedekiah, the last Davidic king, and the Jews by Babylon ruled by Nebuchadnezzar. ${ }^{4}$ Zedekiah became king at the age of twenty-one, being installed by Nebuchadnezzar as his vassal. Extending from 598 вс to 587 BC, Zedekiah's kingship was based on the renunciation of Jewish nationalism, which allowed Babylon to control Israel. However, in the ninth year of his reign, Zedekiah revolted to assert his kingdom's independence. He was captured and brought before Nebuchadnezzar, who killed the nobles of Judah and forced him to watch his sons murdered. Subsequently, Zedekiah was blinded and exiled to Babylon, Jerusalem was sacked, and the Temple destroyed, fulfilling the prophecies in Jeremiah and Ezekiel concerning their fate. ${ }^{5}$

$\begin{array}{ll}2 & \text { Erne, Beyond, } 215 . \\ & \text { Robert Garnier, Les Juifves, ed. Sabine Lardon, rev. }\end{array}$ edn. (Paris, 2004), 11.25-35. All references to the play are from this edition and henceforth will be cited within the text according to line numbers. For an article on Garnier's use of idolatry, see Clive Frankish, 'Idolatry in Garnier's Les Juifves', Bibliothèque d' Humanisme et Renaissance, xxx (1968), 65-83.

4 Zedekiah appears in the following books of the Bible: 2 Kings 24:17-20; 25:1-7; 1 Chronicles $3: 15 ; 2$ Chronicles $36: 10-21$; Jeremiah $1: 3 ; 21: 1-7 ; 24: 8 ; 27: 3,12 ; 28: 1 ; 29: 3$; $32: 1-5 ; 34: 2-8,21 ; 37: 1,3,17,18,21 ; 38: 5,14-26 ; 39: 1-7$; $44: 30 ; 49: 34 ; 51: 59 ; 52: 1-11$; Ezekiel 19:14.

5 Jeremiah 34: 3: 'And thou shalt ... surely be ... delivered into his hand, and thine eies shall beholde the face of the King of Babel, ... and thou shalt go to Babel' (321r); Ezekiel 